\title{
Legal protection of investors, corporate governance, and investable premia in emerging markets
}

\author{
Thomas O'Connor ${ }^{\mathrm{a}, *}$, Stephen Kinsella ${ }^{\mathrm{b}}$, Vincent O'Sullivan ${ }^{\mathrm{b}}$ \\ a Department of Economics, Finance and Accounting, National University of Ireland Maynooth, Maynooth, Co. Kildare, Ireland \\ b Department of Economics, Kemmy Business School, University of Limerick, Limerick, Ireland
}

\section{A R T I C L E I N F O}

\section{Article history:}

Received 8 October 2012

Received in revised form 3 July 2013

Accepted 12 July 2013

Available online 25 July 2013

\section{JEL classification:}

G15

G30

G34

\section{Keywords:}

Investability

Corporate governance

Tobin's $q$

Emerging markets

\begin{abstract}
A B S T R A C T
We examine the interaction between the legal protection of investors, corporate governance, and investable premia in emerging markets. In a multi-country setting and using a novel dataset we find that better-governed firms experience significantly greater stock price increases upon equity market liberalization. We look to see whether well-governed firms in poorly governed countries enjoy an investability premium as measured by Tobin's $q$. We find that they do. Investors look beyond the seemingly weak country-level governance structures, and focus on corporate governance.
\end{abstract}

(c) 2013 Elsevier Inc. All rights reserved.

\section{Introduction}

Over the course of the last two decades, a large literature has examined whether stock market liberalizations have benefited individual firms and the overall economy (see for example Mitton, 2006 for a firm-level analysis, and Bekaert, Harvey, \& Lundblad, 2001, 2005 who examine the gains from stock market liberalizations at the macro level). In general, this literature suggests that stock market liberalizations confer positive benefits on both firms and the economy as a whole. For example, at the firm-level and consistent with international asset pricing models, stock market liberalizations tend to reduce the cost of equity capital as a result of greater risk sharing between domestic and foreign investors. In turn, this lower cost of equity capital manifests in reduced financing constraints (Kim \& Signal, 2000), increased investment (Henry, 2000; Mitton, 2006 using firm-level data), and improved operating performance (Mitton, 2006). Mitton and O'Connor (2012) show that these realized gains impact positively on the value of these firms. Using Tobin's $q$ to proxy for firm value, they uncover an "investable premium" in the region of $9 \%$ for investable firms. At the country (aggregate) level, such reforms have resulted in greater investment and ultimately economic growth (Bekaert et al., 2001, 2005; Gamra, 2009).

However, notwithstanding the positive gains documented in the literature to date, these gains are nonetheless, less than the gains theoretically predicted. One plausible explanation which may explain the apparent reluctance of foreign investors to invest relates to the notion of expropriation risk. ${ }^{1}$ The intuition which underpins this argument is simple and is as follows; the greater

\footnotetext{
* Corresponding author. Tel.:+353 17086667.

E-mail address: Thomas.g.oconnor@nuim.ie (T. O'Connor).

1 While corporate governance standards tend to be higher in developed countries, Klapper and Love (2004) and Durnev and Kim (2005, 2007) show that there exists sizable variation in governance standards within emerging market countries. In turn, they show that the extent of this variation is inversely related to the quality of country governance.
} 
the likelihood of expropriation, the smaller the flow of equity capital to these countries since foreign investors incur sizable monitoring costs should they invest in firms with poor corporate governance. This line of reasoning leads to a simple testable hypothesis; better-governed firms should reap the largest value gains from stock market liberalizations since foreign investors are much more likely to invest in these firms. Bae and Goyal (2010) test this prediction using a sample of firms in the period immediately surrounding the liberalization of the Korean equity market in 1992. They hypothesize that if expropriation risk in part explains the smaller than expected gains from liberalizations, then holding the country governance constant (as their analysis focuses on a single country), and accounting for cross-sectional differences in corporate governance practices among Korean firms, then the largest post-liberalization value gains should accrue to better-governed firms. Using a variety of measures to capture the governance practices of Korean firms, this is in fact what they find. In this paper, we account for cross-sectional differences in corporate and country governance, and examine how their interaction can explain the value gains from stock market liberalizations.

Specifically, in this paper we examine the interaction between the legal protection of investors, corporate governance within firms, and "investable premia" in emerging markets. We generalise the findings of Bae and Goyal (2010), which looked only at South Korea, to a multi-country setting, and largely confirm their insight that better-governed firms experience significantly greater stock price increases upon equity market liberalization.

We go a step further than Bae and Goyal (2010), and deepen that insight by looking to see whether well-governed firms in poorly governed countries enjoy an "investability premium" as measured by Tobin's q, following Mitton and O'Connor (2012). The intuition behind our paper is simple: firms with good corporate governance structures, but in countries with lower levels of foreign investment or weak investor protection should have premia attached to them, as they will flourish in their respective markets, especially with the help of outside capital injections and foreign expertise. In turn, this premium should be larger for these firms than for comparable firms from countries with poor investor protection. Recent evidence suggests that this is in fact the case (Durnev \& Kim, 2005; Chen et al., 2009). Thus, a priori, we would expect that if foreign investors place a large premium on good governance and place an even larger premium when country governance is weak, then better-governed firms from countries with poor governance should enjoy the largest "investable premia". We find that they do. Our findings suggest that investors look beyond the seemingly weak country-level governance structures, and focus on firm-level corporate governance ${ }^{2}$. As such, our findings are consistent with some recent empirical and survey evidence which suggests that firm-level and country-level governance are substitutes for one another in emerging markets and that good corporate governance is more highly valued when country governance is poor (Chen, Chen, \& Wei, 2009; Durnev \& Kim, 2005; McCahery, Sautner, \& Starks, 2010).

The paper begins by carefully describing our data in Section 2, moving on to a discussion of our regression models and results in Section 3, and concludes with a discussion and suggestions for further work in Section 4.

\section{Data description}

We begin by sourcing an initial sample of all 2784 firms from the major markets of the S\&P/IFC Emerging Market Database that were deemed investable at any time between 1980 and 2000. Like Mitton (2006) and Mitton and O'Connor (2012), we measure the openness of a firm's stock to foreign investors using the "investable" measure provided by the EMDB. The S\&P/IFC designates a firm as investable if its stock is free from both country-level and firm-level restrictions on foreign investment. This means that the S\&P/IFC determines whether the market is open to foreign institutions with respect to their ability to buy and sell shares on local stock exchanges and to repatriate capital. Firm-level restrictions refer to corporate by-laws, charters, or industry limitations on the foreign ownership of stock. The S\&P/IFC requires that firms are free from these restrictions. They also require that the stocks have sufficient size (at least $\$ 50$ million in investable market capitalization) and liquidity (at least $\$ 20$ million in annual trading) to be realistically available to foreign investors. We define a firm as investable in a given year if the firm's stock appears in the IFC investable index by December of that year. As a secondary measure of openness we use the "degree open" investable measure, a continuous variable ranging from zero (not open to foreign investors) to one (fully open to foreign investors).

To be included in the final sample, firms must have financial data available in the Worldscope Database and satisfy a number of minimum-data requirements, consistent with both Mitton (2006) and Mitton and O'Connor (2012). First, firms that become investable in the sample period are required to have financial data available at least one year before and one year after the year in which they are first deemed investable. ${ }^{3}$ Second, firms that never become investable are required to have financial data available one year either side of the median year in which firms are first investable in their respective countries. From our initial sample, we lose all firms from the Czech Republic, Egypt, Hungary, Jordan, Morocco, Poland, Russia, Sri Lanka, Slovakia, Venezuela and Zimbabwe due to insufficient financial data.

Our final sample, outlined in Table 1, consists of 251 investable firms from twenty countries. They are Argentina, Brazil, Chile, China, Colombia, Greece, India, Indonesia, Israel, Korea (Republic), Malaysia, Mexico, Pakistan, Peru, Philippines, Portugal, South

\footnotetext{
${ }^{2}$ Kim and Singal (2000) suggest that stock market liberalizations have the potential to improve corporate governance by promoting greater managerial accountability. Cueto (2013) highlights the monitoring role played by institutional investors in Latin American emerging market firms.

${ }^{3}$ There are firms in the final sample that become investable, subsequently become de-investable and investable once again. We require data to be available prior to their initial investable date.
} 
Table 1

Sample statistics by country.

\begin{tabular}{|c|c|c|c|c|c|c|c|c|c|c|c|c|}
\hline & \multicolumn{3}{|c|}{ Full sample } & \multicolumn{2}{|c|}{ Reduced sample } & \multicolumn{3}{|c|}{ Corporate governance measures } & \multirow{2}{*}{$\frac{\mathrm{ADR}}{\mathrm{ADR}}$} & \multicolumn{3}{|l|}{ Key dates } \\
\hline & \# Obs & \# Invest & Total & \# Invest & \# Obs & Invest \& SC & Invest \& DC & Closely held shares (\%) & & First invest & First ADR & Country fund \\
\hline Argentina & 75 & 3 & 12 & 1 & 17 & 2 & 1 & 60.00 & 0 & 1992 & - & 1991 \\
\hline Brazil & 363 & 9 & 53 & 8 & 157 & 1 & 8 & 42.33 & 7 & 1991 & 1994 & 1992 \\
\hline Chile & 265 & 11 & 41 & 11 & 235 & 9 & 2 & 66.71 & 5 & 1992 & 1993 & 1992 \\
\hline China & 313 & 2 & 70 & 2 & 235 & 0 & 2 & 37.29 & 1 & 1992 & 1995 & 1992 \\
\hline Colombia & 63 & 2 & 8 & - & 1 & 1 & 1 & - & 1 & 1991 & 1994 & 1992 \\
\hline Greece & 660 & 20 & 106 & 14 & 147 & 9 & 11 & 61.89 & 1 & 1988 & 1990 & 1998 \\
\hline India & 1123 & 12 & 197 & 3 & 106 & 12 & 0 & 50.83 & 10 & 1991 & 1993 & 1991 \\
\hline Indonesia & 496 & 1 & 79 & 1 & 476 & 0 & 1 & 60.39 & 1 & 1993 & 1996 & 1991 \\
\hline Israel & 91 & 6 & 17 & 6 & 38 & 6 & 0 & 56.00 & 0 & 1994 & - & 1994 \\
\hline Korea & 1317 & 56 & 176 & 55 & 1004 & 56 & 0 & 27.13 & 10 & 1988 & 1991 & 1984 \\
\hline Malaysia & 1671 & 45 & 223 & 45 & 1476 & 45 & 0 & 52.31 & 4 & 1988 & 1992 & 1987 \\
\hline Mexico & 329 & 15 & 36 & 4 & 20 & 4 & 11 & 27.36 & 14 & 1988 & 1991 & 1982 \\
\hline Pakistan & 303 & 3 & 54 & 2 & 66 & 3 & 0 & 70.43 & 0 & 1994 & - & 1994 \\
\hline Peru & 61 & 2 & 14 & 1 & 12 & 0 & 2 & 24.88 & 0 & 1993 & - & NA \\
\hline Philippines & 216 & 5 & 38 & 4 & 80 & 2 & 3 & 58.50 & 3 & 1993 & 1995 & 1990 \\
\hline Portugal & 280 & 9 & 39 & 8 & 156 & 7 & 2 & 56.31 & 2 & 1988 & 1990 & 1987 \\
\hline South Africa & 750 & 23 & 66 & 22 & 599 & 20 & 3 & 55.50 & 18 & 1982 & 1994 & 1994 \\
\hline Taiwan & 538 & 14 & 112 & 4 & 65 & 13 & 1 & 43.69 & 10 & 1990 & 1992 & 1990 \\
\hline Thailand & 874 & 7 & 136 & 5 & 444 & 0 & 7 & 41.56 & 0 & 1989 & 1999 & 1989 \\
\hline \multirow[t]{2}{*}{ Turkey } & 204 & 6 & 33 & 5 & 166 & 6 & 0 & 75.72 & 1 & 1991 & 1994 & 1990 \\
\hline & 9992 & 251 & 1510 & 201 & 5500 & 196 & 55 & 47.19 & 88 & & & \\
\hline
\end{tabular}

The table reports summary statistics of the sample by country. Investable dates are taken from the Emerging Markets Database (EMDB). \# Obs is the number of firm-year observations; \# Inv is the number of investable firms; \# NI is the number of noninvestable firms, and \# Total is the total number of firms. "Reduced Sample" refers to the number of investable (\# Invest) and the number of firm-year observations (\# Obs) when we use closely-held shares (\%). "Invest \& SC" and "Invest \& DC" refers to the number of single- and dual-class investable firms. Closely held shares (\%) is the median pre-investable \% of shares held by insiders in investable firms as a percentage of total common shares outstanding. All information on ADRs is sourced from the Bank of New York, Citibank, NYSE, and NASDAQ. Inv \& SC and Inv \& DC are the number of single and dual-class investable firms, respectively. The number of ADRs refers to the number of firms with ADRs that also have post-listing financial data. First country fund dates are taken form Bekaert et al. (2005) and Patro (2005).

Africa, Taiwan, Thailand, and Turkey. The total number of noninvestable firms is 1259 , which coupled with the number of investable firms' results in a final sample of 1510 firms. In Table 1, we outline by country, the number of investable (\# Inv) and noninvestable (\# NI) firms, the number of firm-year observations (\# Obs), and the total number of firms (\# Total). The number of sample firms per country varies significantly, ranging from a minimum of 8 in Colombia (corresponding to 63 firm-year observations) to a high of 223 in Malaysia (corresponding to $1671 \mathrm{firm}$ year observations). Korea provides the most investable firms (56), while Indonesia provides just one. The total number of firm-year observations is 9992. The final sample covers the period from 1980 to 2000. Our original sample is reduced when we employ the closely-held shares (\%) variable (from Worldscope) to account for differences in corporate governance across firms in our analysis. When we do so, our final sample is now comprised of 5500 firm-year observations and 201 investable firms. In this reduced sample, Colombia no longer contributes any investable firms.

Table 1 also presents three key dates for each country: the first year in which sample firms in each country are designated investable (First Inv); the first year in which a closed-end country fund is available for the country (country fund); and the first year in which a sample firm in the country cross-lists in the United States as an American Depositary Receipt (First ADR). The latter two are included so that we can control for the potential confounding effects of "indirect investability" as Mitton (2006) and Mitton and O'Connor (2012) do, by accounting for the possibility that investable firms become investable, not through stock market liberalizations, but through international cross-listings in the U.S., or through the availability of country-funds. Country fund data is sourced from Bekaert et al. (2005) and Patro (2005). All information on cross-listed firms is sourced from the Bank of New York, and cross-referenced with information from Deutsche Bank, JP Morgan, the New York Stock Exchange, and NASDAQ. We take great care in order to identify a firm's initial listing. To do so, we consult the historical records from the Bank of New York (since the currently available on-line records refer to a firm's current - not previous/initial - cross-listing). We cross-reference this data with the cross-listing database provided by Citibank. They flag firms that have changed their cross-listing status by including a "successor depositary receipt" data type for all firms. South Africa (18) and Mexico (14) provide the greatest number of cross-listing firms.

We employ Tobin's $q$ to measure firm value. Tobin's $q$ is defined here as the book value of debt plus market capitalization divided by the book value of assets. Market value of debt is proxied using its book value counterpart, and the replacement cost of assets as the book value of assets. Book value of debt is calculated as the book value of total assets less the book value of equity. Doidge, Karolyi, and Stulz (2004, 2009), Gozzi, Levine, and Schmukler (2008), and Mitton and O'Connor (2012) also use Tobin's $q$ to proxy for firm value in their studies on the valuation effects of international cross-listings, internationalizations, and investability, respectively. 
All firm-level financial information is sourced from Worldscope for each year from 1980 to 2000. We control for firm and industry related factors commonly employed in other studies using Tobin's $q$. We use the average (geometric) sales growth (inflation-adjusted) over the last two years and global industry $q$ to account for firm and industry growth, respectively. Based upon the general industry classification codes provided by Worldscope, the (yearly) mean global industry $q$ is calculated as the average $q$ of all global firms within each classification. The general industry classification codes are; 1 (Industrial), 2 (Utility), 3 (Transportation), 4 (Bank/Savings \& Loan), 5 (Insurance), 6 (Other Financial). We use the log of sales (inflation-adjusted and in \$U.S.), rather than total assets (given the definition of Tobin's $q$ ) to control for firm size. Tobin's $q$, sales growth, and firm size are winsorized at the 1 and $99 \%$ tails of the distribution to remove the confounding effects of outliers. Finally, we exclude financial firms (general industry classification codes 4, 5, and 6) since these firms are more likely to be valued differently from non-financial firms.

We use two measures to measure the strength of corporate governance. The first measure of corporate governance is an indicator variable that takes the value of one if the firm is a dual-class share firm (DC), and zero for a single-class share firm (SC). ${ }^{4}$ To classify firms as either SC or DC, we employ the 'Currently a Multiple Share Company' from Worldscope. It identifies multiple share companies as "...companies which currently have more than one type of common/ordinary share". ${ }^{5}$ Our final sample is comprised of 196 single-class and 55 dual-class share investable firms. ${ }^{6}$ Korea (56) and Malaysia (45) provide the most single-class share investable firms. China, Indonesia, Peru and Thailand provide none. Both Greece and Mexico (11) contribute the greatest amount of dual-class share investable firms to our final sample.

Our second measure of corporate governance, also sourced from Worldscope, is the number of shares held by insiders as a percentage of the total number of shares outstanding. Firms with a larger percentage of closely held shares (as a percentage of total common shares outstanding) are likely to suffer less from agency conflicts since the incentives of the controlling insiders are likely to be better aligned with those of non-controlling minority outsiders. Consistent with this view, Mitton (2002) and Claessens et al. (2002) show how firm profitability and value is greater the larger the ownership (cash-flow) stake held by controlling insiders. In Table 1, we outline the pre-investable level of closely held shares held by the median investable firm. Inside ownership tends to be highest in Pakistan (70.43\%) and Turkey (75.72\%) and much lower in Mexico (27.36\%) and Korea (27.13\%).

Finally, we employ a number of different measures to try and capture the level of country-level investor protection in each of our sample of twenty countries. First, we use the Kaufmann, Kraay, and Mastruzzi (2007) measure of institutional development. This measure, available on a semi-annual basis from 1996 to 2000, and an annual basis from 2000, is comprised of six components, namely, voice and accountability, political stability, government effectiveness, regulatory quality, rule of law, and control of corruption. We calculate institutional development as the sum of each of these six variables in each year, averaged over the years 1996, 1998, and 2000, to coincide with our sample period. We also use Spamann's (2010) "corrected" anti-director rights index (using 1997 values), the judicial efficiency measure from La Porta, Lopez-de-Silanes, Shleifer, and Vishny (1998), investor protection from La Porta, Lopez-de-Silanes, and Shleifer (2006), and a measure of accounting standards from CIFAR (Center for International Financial Analysis \& Research). Anti-director rights is an index that aggregates six different shareholder rights and ranges in value from 0 to 6 with 6 the highest level of protection for minority shareholders. Efficiency of the judicial system is an assessment of the efficiency and integrity of the legal environment as it affects business and ranges in value from 1 to 10, with 10 the highest level of efficiency. Investor Protection is calculated as the weighted average of disclosure, liability standards, and (original) anti-director rights using principal component analysis. Investor Protection ranges from a low of zero to a high of ten, where higher values correspond to better levels of investor protection. The index of accounting disclosure level is measured in 1995 and is created by examining and rating companies' annual reports for their inclusion and exclusion of 85 items and ranges from 0 to 100 with 100 as the highest accounting standard. The value of each of these institutional development measures are outlined for each country in Table 2 . The bottom row presents the country sample median for each variable. All figures in bold refer to values of each measure above the sample median. Institutions tend to be of high-quality in Chile, Portugal, and Taiwan, and much less so in Pakistan and Indonesia. Based on Spamann's (2010) anti-director rights index, shareholders enjoy considerable legal protection in Brazil, Chile, Pakistan, South Africa, and Taiwan (all 5), and much less so in Mexico (2). The judiciary tends to be most efficient in Israel and Taiwan (both 10), and least efficient in Indonesia (2.50). Investor protection is greatest in the Philippines and India. Finally, accounting standards tend to be greatest in Malaysia and South Africa (both 79).

\footnotetext{
${ }^{4}$ Durnev and Kim $(2005,2007)$ show using CLSA and S\&P corporate governance data that in firms where control rights exceed cashflow rights (e.g. dual-class share firms), corporate governance standards tend to be lower in these firms, relative to firms where no such differences (or much smaller differences) exist between control and cashflow rights (e.g. single-class share firms). Consistent with the view, the consumption of private benefits tends to be greater in firms with dual-class shares compared to firms with single-class share structures (DeAngelo \& DeAngelo, 1985; Grossman \& Hart, 1988, and more recently, Masulis et al., 2009). As a result, dual-class share firms tend to trade at a discount relative to single-class share companies (Durnev \& Kim, 2005; Lins, 2003).

${ }^{5}$ Durnev and Kim $(2005,2007)$ show using CLSA and S\&P corporate governance data that in firms where control rights exceed cashflow rights (e.g. dual-class share firms), corporate governance standards tend to be lower in these firms, relative to firms where no such differences (or much smaller differences) exist between control and cashflow rights (e.g. single-class share firms). Consistent with the view, the consumption of private benefits tends to be greater in firms with dual-class shares compared to firms with single-class share structures (DeAngelo \& DeAngelo, 1985; Grossman \& Hart, 1988, and more recently, Masulis, Wang, \& Xie, 2009). As a result, dual-class share firms tend to trade at a discount relative to single-class share companies (Durnev \& Kim, 2005; Lins, 2003).

${ }^{6}$ Claessens, Djankov, Fan, and Lang (2002) and Lins (2003) show that governance problems, arising from dual-class share structures are common in emerging markets.
} 
Table 2

Institutional development/country governance measures.

\begin{tabular}{|c|c|c|c|c|c|c|c|c|c|c|c|}
\hline & VA & PS & GE & RQ & $\mathrm{RL}$ & $\mathrm{CC}$ & ID & ADRI & $\mathrm{JE}$ & IP & ADI \\
\hline Argentina & 0.273 & 0.097 & 0.197 & 0.582 & 0.063 & $(0.176)$ & 1.036 & 3 & 6.00 & 0.479 & 68 \\
\hline Brazil & 0.182 & $(0.267)$ & $(0.108)$ & 0.319 & $(0.237)$ & 0.020 & $(0.091)$ & 5 & 5.75 & 0.442 & 56 \\
\hline Chile & 0.678 & 0.444 & 1.136 & 1.339 & 1.230 & 1.354 & 6.181 & 5 & 7.25 & 0.610 & 78 \\
\hline China & $(1.440)$ & $(0.151)$ & $(0.080)$ & $(0.130)$ & $(0.335)$ & $(0.207)$ & $(2.343)$ & Low & Low & Low & Low \\
\hline Colombia & $(0.524)$ & $(1.587)$ & $(0.167)$ & 0.242 & $(0.785)$ & $(0.581)$ & (3.403) & 4 & 7.25 & 0.355 & 58 \\
\hline Greece & 0.921 & 0.431 & 0.771 & 0.779 & 0.864 & 0.576 & 4.342 & 3 & 7.00 & Low & 61 \\
\hline India & 0.236 & $(0.848)$ & $(0.162)$ & $(0.171)$ & 0.266 & $(0.364)$ & $(1.042)$ & 4 & 8.00 & 0.769 & 61 \\
\hline Indonesia & $(0.868)$ & $(1.311)$ & $(0.431)$ & $(0.077)$ & $(0.615)$ & $(0.884)$ & $(4.186)$ & 4 & 2.50 & 0.507 & Low \\
\hline Israel & 0.705 & $(0.856)$ & 1.059 & 1.057 & 1.114 & 1.241 & 4.319 & 3 & 10.00 & 0.594 & 74 \\
\hline Korea & 0.576 & 0.190 & 0.692 & 0.457 & 0.772 & 0.306 & 2.992 & 4 & 6.00 & 0.358 & 68 \\
\hline Malaysia & $(0.271)$ & 0.362 & 0.762 & 0.548 & 0.543 & 0.516 & 2.460 & 4 & 9.00 & 0.729 & 79 \\
\hline Mexico & $(0.022)$ & $(0.480)$ & 0.201 & 0.458 & $(0.445)$ & $(0.390)$ & $(0.676)$ & 2 & 6.00 & Low & 71 \\
\hline Pakistan & $(0.935)$ & $(1.267)$ & $(0.614)$ & $(0.517)$ & $(0.695)$ & $(0.861)$ & $(4.889)$ & 5 & 5.00 & 0.625 & 73 \\
\hline Peru & $(0.332)$ & $(0.994)$ & $(0.143)$ & 0.530 & $(0.613)$ & $(0.189)$ & $(1.740)$ & 4 & 6.75 & 0.656 & High \\
\hline Philippines & 0.247 & $(0.454)$ & $(0.197)$ & 0.328 & $(0.177)$ & $(0.409)$ & $(0.662)$ & 4 & 4.75 & 0.812 & 64 \\
\hline Portugal & 1.352 & 1.212 & 1.178 & 1.059 & 1.206 & 1.350 & 7.359 & 3 & 5.50 & 0.574 & 56 \\
\hline South Africa & 0.830 & $(0.795)$ & 0.753 & 0.236 & 0.127 & 0.569 & 1.721 & 5 & 6.00 & 0.599 & 79 \\
\hline Taiwan & 0.729 & 0.789 & 1.055 & 1.007 & 0.888 & 0.824 & 5.291 & 5 & 10.00 & 0.547 & 58 \\
\hline Thailand & 0.400 & 0.285 & 0.218 & 0.356 & 0.535 & $(0.172)$ & 1.622 & 4 & 6.75 & High & 66 \\
\hline Turkey & $(0.532)$ & $(1.137)$ & $(0.064)$ & 0.417 & $(0.049)$ & $(0.153)$ & $(1.518)$ & 4 & 4.00 & 0.338 & 58 \\
\hline \multicolumn{12}{|c|}{ Country sample medians } \\
\hline & 0.241 & $(0.361)$ & 0.199 & 0.437 & 0.095 & $(0.163)$ & 0.473 & 4 & 6.00 & 0.584 & 66 \\
\hline
\end{tabular}

The table reports institutional development measures by country. Figures in bold refer to measures above the country sample median. Institutional development (ID) is averaged over 1996, 1998, and 2000, and is the sum of Voice \& Accountability (VA), Political Stability (PS), Government Effectiveness (GE), Regulatory Quality (RQ), Rule of Law (RL), and Control of Corruption (CC). ADRI is Spamann's (2010) "corrected" anti-director rights index, JD is judicial efficiency, IP is investor protection, and ADI is accounting disclosure index. The Spamann (2010) "corrected" anti-director rights index is not available for China nor Indonesia. We assume that China is below the sample median, and use the revised anti-director rights index from Djankov, La Porta, Lopez-de-Silanes, and Shleifer (2008) for Indonesia. We also assume that China has below-median values of Judicial Efficiency, Investor Protection, and Accounting Disclosure. We assume that Greece and Mexico have below-median values (Low) of Investor Protection, and Thailand above-median (High). For the Accounting Disclosure Index, we assume below-median values for Indonesia and above-median for Peru.

\section{Regression analysis}

This section explores the relationship between investability, corporate governance, investor protection (country governance), and firm value. We begin by replicating Mitton and O'Connor (2012), by first establishing the existence of "investable premia". Then, we examine how these "investable premia" vary by level of country-level investor protection, and corporate governance. Finally, we examine how the interaction of country-level investor protection and corporate governance explain the "investable premia".

First, and in line with Mitton and O'Connor (2012), we first try to establish a causal link between investability and firm value. The results are outlined in Table 3. To do so, we estimate a series of firm-fixed effects regressions of the following form:

$$
\text { Tobin's } q_{\text {it }}=\alpha+\beta X_{\text {it }}+\text { Investable }_{\text {it }}+\text { Year }_{\mathrm{t}}+\text { Firm }_{\mathrm{i}}+\varepsilon_{\mathrm{it}}
$$

where Tobin's $q_{\mathrm{it}}$ is Tobin's $q$ for firm i in year $\mathrm{t}, \mathrm{X}_{\mathrm{it}}$ is a set of firm and industry controls (sales growth, size, global industry $q$ ), and Investable are 0/1 dummies. Year ${ }_{t}$ and Firm $_{i}$ represent a full set of year and firm fixed-effects. The coefficient estimates are outlined in Table 3, with t-statistics calculated using standard errors adjusted for firm-level clustering reported in parentheses underneath (Petersen, 2009).

In column 1 of Table 3, we regress Tobin's $q$ on the investable dummies alone (time and fixed effects are included). In subsequent columns, we sequentially add firm and industry level control variables. Column 4 presents the coefficient estimates with all firm and industry-level control variables included (and time and firm fixed-effects). In the remaining columns of Table 3, we control for the potentially confounding effects of indirect investability. Since some of our firms are indirectly investable through ADR issuance or through inclusion in a country-fund, we need to separate the value gains from direct investability (equity market liberalizations) from indirect investability (ADR issuance/country fund inclusion). To do so, we include the investable dummies with either ADR dummies or country fund dummies in the remaining columns of Table 3. In column 5 , we add cross-listing dummy variables to column 4 . In column 6 , country fund data is added to the specification in column 4. In column 7, cross-listing and country fund data are included simultaneously.

The coefficient estimates on the investable dummies are positive and statistically significant in all regressions, ranging from 0.111 to 0.150 , with an average coefficient estimate of 0.128 . These findings suggest that in as much as we can control for observable and unobservable differences between investable and noninvestable firms, investable firms are worth more than 
Table 3

Regression estimates of the effect of investability on firm value.

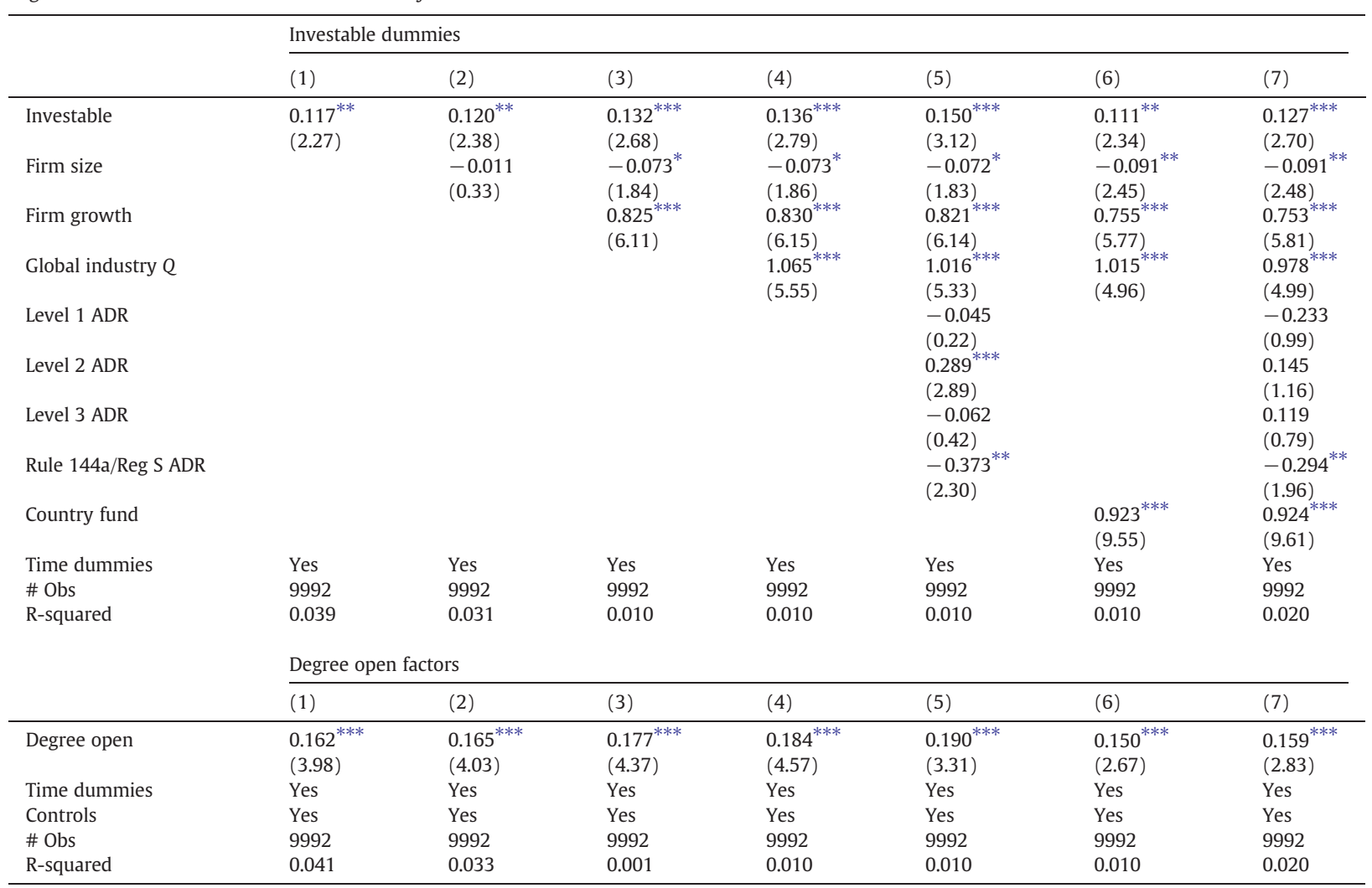

The table reports coefficient estimates from firm-fixed effects regressions with t-statistics (absolute value) adjusted for firm-level clustering presented in parentheses underneath the coefficient estimates. The dependent variable is Tobin's q. Openness to foreign investors is measured using either investable dummies or degree-open factors, respectively. Investable is a dummy variable that is set equal to one in years in which the firm is designated as investable. The degree open factor ranges from zero (not open to foreign investors) to one (fully open to foreign investors). Firms are deemed investable if its stock is free from size is measured as the log of both country-level and firm-level restrictions on foreign investment. Firm annual sales in real \$U.S. Firm growth is measured as the (geometric) average real growth in sales over the prior two years. Global industry $q$ is calculated as the average $q$ of all global firms within each industry classification. ADR variables are dummy variables that are set equal to one in years in which the firm has an ADR. Country fund is a dummy variable indicating the existence of a closed-end country fund in the firm's country. Also estimated but not reported are a constant, and a full set of year dummies.

*** Statistical significance for the $1 \%$ level.

** Statistical significance for the $5 \%$ level.

* Statistical significance for the $10 \%$ level.

noninvestable firms. These findings are in line with Mitton and O'Connor (2012). Furthermore, since the median investable firm has a Tobin's $q$ of 1.20 , this suggests that the act of becoming fully investable causes an average change in value of $10.67 \%$ (i.e., $(0.128 / 1.20) * 100)$ for these firms.

When we control for 'indirect investability', we find that the coefficient estimates on the investable remain high, and retain their statistical significance. The value gains from becoming investable via equity market liberalizations are distinct from the gains from ADR or country fund issuance.

We document a "cross-listing premium" for Level 2 firm only. For our sample of Rule 144a/Reg S firms, cross-listing only serves to destroy value. Country fund availability enhances firm value. Finally, the control variables tend to be of the correct sign, and statistically significant. Firm value increases with firm and industry growth, while smaller firms tend to be worth more. In the bottom rows of Table 3, we estimate Eq. (1), but now, we measure openness to foreign investment using degree-open factors, a continuous variable ranging from zero (not open to foreign investors) to one (fully open to foreign investors). The coefficient estimates using the degree-open factors only serve to reinforce the findings just presented. Again, in all specifications, the coefficient estimates on the degree-open factors are positive and always statistically significant. These findings confirm the findings of Mitton and O'Connor (2012). ${ }^{7}$

In Table 4 we examine whether investable firms are worth more than and noninvestable firms around the time of investability. To do so, we create a series of event-time investable dummies which are equal to 1 in the specified year (and zero otherwise).

\footnotetext{
${ }^{7}$ In the remainder of the paper, we only present coefficient estimates using the investable dummies. Our findings remain unchanged when we also use degreeopen factors.
} 
Table 4

Regression estimates of the effect of investability on firm value around the time of becoming investables.

\begin{tabular}{|c|c|c|c|c|c|c|c|}
\hline & \multicolumn{7}{|c|}{ Investable dummies } \\
\hline & $(1)$ & $(2)$ & (3) & (4) & (5) & (6) & (7) \\
\hline$>3$ Years Before & $\begin{array}{l}0.107 \\
(1.42)\end{array}$ & $\begin{array}{l}0.101 \\
(1.33)\end{array}$ & $\begin{array}{l}0.100 \\
(1.31)\end{array}$ & $\begin{array}{l}0.065 \\
(0.85)\end{array}$ & $\begin{array}{l}0.064 \\
(0.85)\end{array}$ & $\begin{array}{l}0.078 \\
(1.07)\end{array}$ & $\begin{array}{l}0.078 \\
(1.07)\end{array}$ \\
\hline 3 years before & $\begin{array}{l}0.156 \\
(1.62)\end{array}$ & $\begin{array}{l}0.151 \\
(1.55)\end{array}$ & $\begin{array}{l}0.150 \\
(1.53)\end{array}$ & $\begin{array}{l}0.132 \\
(1.34)\end{array}$ & $\begin{array}{l}0.132 \\
(1.34)\end{array}$ & $\begin{array}{l}0.159 \\
(1.62)\end{array}$ & $\begin{array}{l}0.159 \\
(1.62)\end{array}$ \\
\hline 2 Years Before & $\begin{array}{l}0.137^{*} \\
(1.86)\end{array}$ & $\begin{array}{l}0.131^{*} \\
(1.77)\end{array}$ & $\begin{array}{l}0.135^{*} \\
(1.83)\end{array}$ & $\begin{array}{l}0.131^{*} \\
(1.77)\end{array}$ & $\begin{array}{l}0.128^{*} \\
(1.73)\end{array}$ & $\begin{array}{l}0.164^{* *} \\
(2.24)\end{array}$ & $\begin{array}{l}0.161^{* *} \\
(2.21)\end{array}$ \\
\hline 1 year before & $\begin{array}{l}0.330^{* * *} \\
(5.23)\end{array}$ & $\begin{array}{l}0.324^{\text {*** }} \\
(5.05)\end{array}$ & $\begin{array}{l}0.322^{\text {*** }} \\
(5.11)\end{array}$ & $\begin{array}{l}0.315^{\text {*** }} \\
(5.01)\end{array}$ & $\begin{array}{l}0.314^{\text {*** }} \\
(5.00)\end{array}$ & $\begin{array}{l}0.293^{\text {*** }} \\
(4.68)\end{array}$ & $\begin{array}{l}0.293^{\text {*** }} \\
(4.68)\end{array}$ \\
\hline Investable year & $\begin{array}{l}0.371^{\text {*** }} \\
(5.41)\end{array}$ & $\begin{array}{l}0.365^{\text {*** }} \\
(5.22)\end{array}$ & $\begin{array}{l}0.361^{* * *} \\
(5.24)\end{array}$ & $\begin{array}{l}0.353^{* * *} \\
(5.15)\end{array}$ & $\begin{array}{l}0.354^{\text {*** }} \\
(5.16)\end{array}$ & $\begin{array}{l}0.362^{* * *} \\
(5.35)\end{array}$ & $\begin{array}{l}0.363^{\text {*** }} \\
(5.37)\end{array}$ \\
\hline 1 Year After & $\begin{array}{l}0.196^{\text {*** }} \\
(3.02)\end{array}$ & $\begin{array}{l}0.189^{* * *} \\
(2.86)\end{array}$ & $\begin{array}{l}0.206^{\text {*** }} \\
(3.16)\end{array}$ & $\begin{array}{l}0.196^{* * *} \\
(3.01)\end{array}$ & $\begin{array}{l}0.197^{\text {*** }} \\
(3.06)\end{array}$ & $\begin{array}{l}0.232^{* * *} \\
(3.58)\end{array}$ & $\begin{array}{l}0.233^{\text {*** }} \\
(3.65)\end{array}$ \\
\hline 2 Years After & $\begin{array}{l}0.167^{\text {*** }} \\
(2.77)\end{array}$ & $\begin{array}{l}0.159^{* * *} \\
(2.61)\end{array}$ & $\begin{array}{l}0.188^{\text {*** }} \\
(3.10)\end{array}$ & $\begin{array}{l}0.182^{\text {*** }} \\
(2.99)\end{array}$ & $\begin{array}{l}0.183^{\text {*** }} \\
(3.04)\end{array}$ & $\begin{array}{l}0.147^{* *} \\
(2.47)\end{array}$ & $\begin{array}{l}0.150^{* *} \\
(2.54)\end{array}$ \\
\hline 3 Years After & $\begin{array}{l}0.196^{\text {*** }} \\
(3.42)\end{array}$ & $\begin{array}{l}0.188^{* * *} \\
(3.19)\end{array}$ & $\begin{array}{l}0.210^{* * * *} \\
(3.60)\end{array}$ & $\begin{array}{l}0.207^{\text {*** }} \\
(3.57)\end{array}$ & $\begin{array}{l}0.209^{* * *} \\
(3.63)\end{array}$ & $\begin{array}{l}0.177^{* * *} \\
(3.14)\end{array}$ & $\begin{array}{l}0.181^{* * *} \\
(3.23)\end{array}$ \\
\hline 4 Years After & $\begin{array}{l}0.143^{* *} \\
(2.17)\end{array}$ & $\begin{array}{l}0.135^{* *} \\
(2.01)\end{array}$ & $\begin{array}{l}0.167^{* *} \\
(2.49)\end{array}$ & $\begin{array}{l}0.167^{* *} \\
(2.50)\end{array}$ & $\begin{array}{l}0.166^{* *} \\
(2.51)\end{array}$ & $\begin{array}{l}0.142^{* *} \\
(2.21)\end{array}$ & $\begin{array}{l}0.144^{* *} \\
(2.25)\end{array}$ \\
\hline 5 Years After & $\begin{array}{l}0.063 \\
(0.98)\end{array}$ & $\begin{array}{l}0.055 \\
(0.54)\end{array}$ & $\begin{array}{l}0.108^{*} \\
(1.67)\end{array}$ & $\begin{array}{l}0.094 \\
(1.44)\end{array}$ & $\begin{array}{l}0.091 \\
(1.39)\end{array}$ & $\begin{array}{l}0.087 \\
(1.42)\end{array}$ & $\begin{array}{l}0.088 \\
(1.41)\end{array}$ \\
\hline$>5$ Years After & $\begin{array}{l}0.126^{\text {*** }} \\
(2.69)\end{array}$ & $\begin{array}{l}0.116^{* *} \\
(2.36)\end{array}$ & $\begin{array}{l}0.158^{* * *} \\
(3.22)\end{array}$ & $\begin{array}{l}0.152^{* * *} \\
(3.09)\end{array}$ & $\begin{array}{l}0.145^{\text {*** }} \\
(2.84)\end{array}$ & $\begin{array}{l}0.162^{* * * *} \\
(3.34)\end{array}$ & $\begin{array}{l}0.162^{\text {*** }} \\
(3.21)\end{array}$ \\
\hline Firm size & & $\begin{array}{l}0.010 \\
(0.54)\end{array}$ & $\begin{array}{l}-0.016 \\
(1.52)\end{array}$ & $\begin{array}{l}-0.016 \\
(1.57)\end{array}$ & $\begin{array}{l}-0.015 \\
(1.45)\end{array}$ & $\begin{array}{l}-0.018^{*} \\
(1.78)\end{array}$ & $\begin{array}{l}-0.017^{*} \\
(1.65)\end{array}$ \\
\hline Firm growth & & & $\begin{array}{l}1.012^{* * *} \\
(9.53)\end{array}$ & $\begin{array}{l}1.021^{* * *} \\
(9.62)\end{array}$ & $\begin{array}{l}1.016^{\text {*** }} \\
(9.55)\end{array}$ & $\begin{array}{l}0.869^{* * *} \\
(8.32)\end{array}$ & $\begin{array}{l}0.865^{* * *} \\
(8.28)\end{array}$ \\
\hline Global industry $Q$ & & & & $\begin{array}{l}1.099^{* * *} \\
(7.77)\end{array}$ & $\begin{array}{l}1.096^{* * *} \\
(7.71)\end{array}$ & $\begin{array}{l}1.079^{* * *} \\
(7.55)\end{array}$ & $\begin{array}{l}1.078^{* * *} \\
(7.51)\end{array}$ \\
\hline Level 1 ADR & & & & & $\begin{array}{l}0.311^{\text {*** }} \\
(2.77)\end{array}$ & & $\begin{array}{l}0.242^{* *} \\
(2.16)\end{array}$ \\
\hline Level 2 ADR & & & & & $\begin{array}{l}-0.020 \\
(0.22)\end{array}$ & & $\begin{array}{l}-0.083 \\
(0.87)\end{array}$ \\
\hline Level 3 ADR & & & & & $\begin{array}{l}-0.113^{* * *} \\
(2.65)\end{array}$ & & $\begin{array}{l}-0.067 \\
(0.97)\end{array}$ \\
\hline Rule 144a/Reg S ADR & & & & & $\begin{array}{l}-0.131^{\text {*** }} \\
(2.65)\end{array}$ & & $\begin{array}{l}-0.136^{* * *} \\
(2.75)\end{array}$ \\
\hline Country fund & & & & & & $\begin{array}{l}1.081^{\text {*** }} \\
(15.60)\end{array}$ & $\begin{array}{l}1.076^{\text {*** }} \\
(15.46)\end{array}$ \\
\hline Time dummies & Yes & Yes & Yes & Yes & Yes & Yes & Yes \\
\hline Country dummies & Yes & Yes & Yes & Yes & Yes & Yes & Yes \\
\hline \# Obs & 9992 & 9992 & 9992 & 9992 & 9992 & 9992 & 9992 \\
\hline R-squared & 0.156 & 0.158 & 0.168 & 0.172 & 0.173 & 0.209 & 0.210 \\
\hline
\end{tabular}

The table reports coefficient estimates from pooled regressions with t-statistics (absolute value) adjusted for firm-level clustering presented in parentheses underneath the coefficient estimates. The dependent variable is Tobin's q. Openness to foreign investors is measured using investable dummies. The single year investability dummies equal one in the indicated year and zero otherwise. The "> 3 Years Before" dummy equals 1 in all years prior to three years before becoming investable. The ">5 Years After" dummy equals one after the fifth year of investability and zero otherwise. Firms are deemed investable if its stock is free from both country-level and firm-level restrictions on foreign investment. Firm size is measured as the log of annual sales in real \$U.S. Firm growth is measured as the (geometric) average real growth in sales over the prior two years. Global industry $q$ is calculated as the average $q$ of all global firms within each industry classification. ADR variables are dummy variables that are set equal to one in years in which the firm has an ADR. Country fund is a dummy variable indicating the existence of a closed-end country fund in the firm's country. Also estimated but not reported are a constant, and a full set of year and country dummies.

*** Statistical significance for the $1 \%$ level.

** Statistical significance for the $5 \%$ level.

* Statistical significance for the $10 \%$ level.

The "> 3 Years Before" event dummy equals one in each year more than 3 years prior to the investable date. The ">5 Years After" event dummy equals one in all years after the firm has been investable for five years. This exercise is identical to that undertaken by Gozzi et al. (2008), Doidge et al. (2009), and O'Connor (2010) for international, cross-listing, and investable firms, respectively. In all regressions, the benchmark sample is noninvestable firms. Before we examine the findings in Table 4, first consider Fig. 1 . Fig. 1 displays the value of investable firms (graph on left of Fig. 1), and relative to noninvestable firms (graph on right of Fig. 1) in each year from 5 years prior to becoming investable to 10 years after. Year " 0 " is the investable year. These figures suggest that investable firms experience an increase in value, both on an absolute basis, and relative to noninvestable firms in the years immediately prior to becoming investable. Firm value peaks at the time of becoming investable, and then tends to fall-off, but it then appears to appreciate again once firms are investable for at least five years. O'Connor (2010) shows that this recovery in value after five years is long-lasting and permanent. The coefficients outlined in Table 4 suggest likewise. First, and consistent with Fig. 1, investable firms experience an 


\section{Investability and Tobin's $q$}

Tobin's $q$

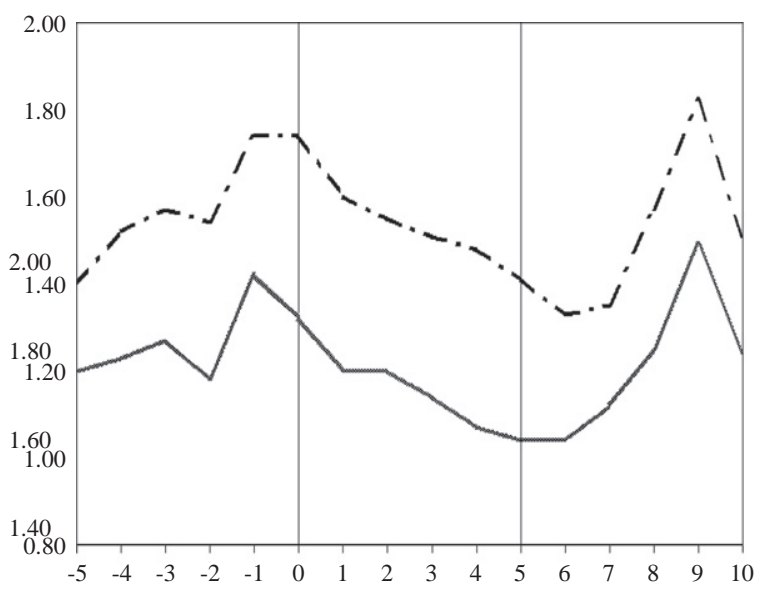

1.20

- Median - Mean

1.00

0.80

$\begin{array}{llllllllllllllll}-5 & -4 & -3 & -2 & -1 & 0 & 1 & 2 & 3 & 4 & 5 & 6 & 7 & 8 & 9 & 10\end{array}$
Relative Tobin's $q$

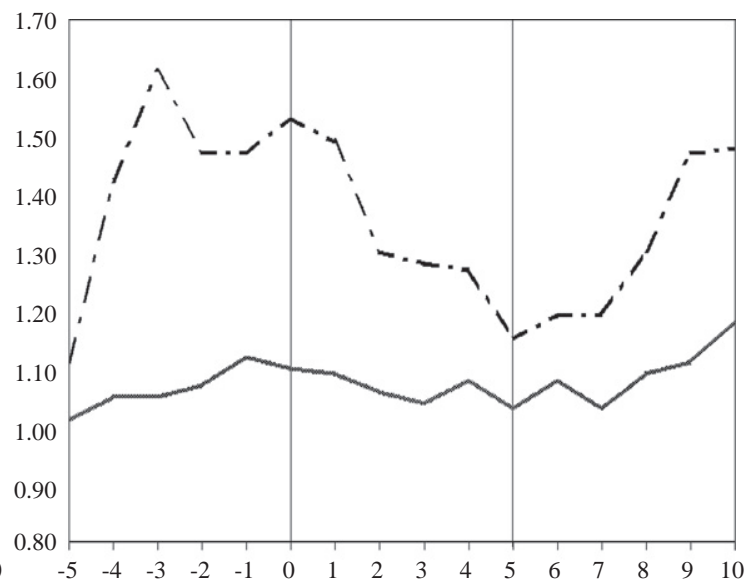

- Median - Mean

1.00

0.90

0.80

$\begin{array}{llllllllllllllll}-5 & -4 & -3 & -2 & -1 & 0 & 1 & 2 & 3 & 4 & 5 & 6 & 7 & 8 & 9 & 10\end{array}$

Median Mean

Median Mean

Fig. 1. Investability and Tobin's $q$. Notes: This figure displays the mean and median value of investable firms from five years prior to becoming investable to ten years after. The top row displays the mean and median absolute and relative value of investable firms. Absolute value is measured using Tobin's $q$. Relative value is measured using median-adjusted relative $q$. Median-adjusted relative Tobin's $q$ is calculated as the value of each investable firm divided by the median value of all noninvestable firms in each firm's home country (in each year).

increase in value in the years leading up to becoming investable. The "valuation premium" for investable over noninvestable firms manifests two-years before the investable date (the average coefficient estimate on the "2 Years Before" event dummy is 0.141), peaks on the investable year (the average coefficient estimate is 0.361 on the "Investable Date"), falls off thereafter, but recovers, which suggests that investable firms enjoy a permanent valuation premium over noninvestable firms. The average coefficient estimate on the "> 5 Years After" event dummy is 0.146 , which results in an average valuation premium for investable firms over the average noninvestable firm (average value is 1.34 ) of $10.89 \%(0.146 / 1.34) * 100)$. The value of international and cross-listing firms exhibits behavior similar to investable firms in the years immediately prior and subsequent to become international/cross-listing. Gozzi et al. (2008) suggest that unlike investable firms, there is no long-lasting permanent valuation premium for these firms. Doidge et al. (2009) suggest otherwise for cross-listing firms.

\subsection{Investability and country-level investor protection}

To expand on Mitton and O'Connor (2012), in Table 5 we estimate the impact of investability on firm value by the strength of country-level investor protection. Separate regressions are estimated for firms domiciled in countries with high (above-median) and low (below-median) country-level investor protection, based on the (country) median figures outlined in Table 2. Mitton and O'Connor (2012) perform a similar analysis in a working paper version of their paper. In their paper, they estimate separate regressions for investable firms by level of financial development. Here, in this paper, we employ a set of variables designed to capture other and much broader aspects of country-level investor protection.

In columns 1 through 4 of Panel A, we estimate Eq. (1) separately for firms in countries with high-and low-quality institutions. Firm-level controls are included, but not reported. The coefficient estimates suggest that investable firms from countries with low-quality institutions experience much larger increases in value once they become investable (the coefficient estimates range from 0.731 to 0.759 ). In contrast, for investable firms in countries with strong institutions, the coefficient estimates on the investable dummies are much lower and never statistically different to zero. These findings are largely repeated when we use the other four measures of country-level investor protection, namely shareholder rights (using Spamann's (2010) 'corrected' anti-director rights measure (using 1997 values)), judicial efficiency, investor protection, and accounting standards. In all four instances, the coefficient estimates on the investable dummy are greater for investable firms in countries where investor protection is weak, and the differences are statistically different in three of the four cases. For example, using accounting standards, the coefficient estimates range from 0.073 ( $t$-stat is 1.28 and thus statistically insignificant) where accounting 
Table 5

Regression estimates of the effect of investability on firm value by country level investor protection.

\begin{tabular}{|c|c|c|c|c|c|c|}
\hline \multicolumn{7}{|l|}{ Panel A } \\
\hline \multirow[b]{2}{*}{ Investable } & \multicolumn{3}{|c|}{ High institutional development } & \multicolumn{3}{|c|}{ Low institutional development } \\
\hline & $0.040(0.88)$ & $0.052(1.17)$ & $-0.010(0.15)$ & $0.731^{* * *}(3.86)$ & $\begin{array}{l}0.759^{\text {*** }} \\
(4.00)\end{array}$ & $\begin{array}{l}0.735^{\text {*** }} \\
(3.87)\end{array}$ \\
\hline Time dummies & Yes & Yes & Yes & Yes & Yes & Yes \\
\hline Controls & Yes & Yes & Yes & Yes & Yes & Yes \\
\hline \# Obs & 6521 & 6521 & 6521 & 3471 & 3471 & 3471 \\
\hline R-squared & 0.010 & 0.011 & 0.012 & 0.010 & 0.010 & 0.010 \\
\hline
\end{tabular}

t-stat: High vs. Low $2.74^{* * *}$

Panel B

\begin{tabular}{|c|c|c|c|c|c|c|c|c|}
\hline & \multicolumn{2}{|c|}{$\begin{array}{l}\text { Spamann ADR Index } \\
\text { (1997 Values) }\end{array}$} & \multicolumn{2}{|c|}{ Judicial Efficiency } & \multicolumn{2}{|c|}{ Investor Protection } & \multicolumn{2}{|c|}{ Accounting Disclosures } \\
\hline & High ADRI & Low ADRI & High JE & Low JE & High IP & Low IP & High ADI & Low ADI \\
\hline & (1) & $(2)$ & (3) & $(4)$ & $(5)$ & $(6)$ & $(7)$ & $(8)$ \\
\hline Investable & $0.140^{\text {**** }}(2.71)$ & $0.389^{* * *}(2.76)$ & $0.089^{*}(1.71)$ & $0.360^{* * *}(2.98)$ & $0.055(0.82)$ & $0.144^{* *}(2.38)$ & $0.073(1.28)$ & $0.296^{\text {*** }}(3.59)$ \\
\hline Time dummies & Yes & Yes & Yes & Yes & Yes & Yes & Yes & Yes \\
\hline Controls & Yes & Yes & Yes & Yes & Yes & Yes & Yes & Yes \\
\hline \# Obs & 8244 & 1748 & 7817 & 2175 & 5354 & 4638 & 6232 & 3760 \\
\hline \multirow[t]{2}{*}{ R-squared } & 0.001 & 0.146 & 0.046 & 0.010 & 0.048 & 0.036 & 0.010 & 0.035 \\
\hline & \multicolumn{8}{|c|}{ Significance tests: High ID vs. Low } \\
\hline t-stat: High vs. Low & $1.66^{*}$ & & $1.69^{*}$ & & 0.95 & & $2.67^{* * * *}$ & \\
\hline
\end{tabular}

The table reports coefficient estimates from firm-fixed effects regressions with t-statistics (absolute value) adjusted for firm-level clustering presented in parentheses underneath the coefficient estimates. Separate regressions are estimated for firms domiciled in countries with high (above-median) and low (below-median) country-level investor protection. Investor protection is measured using either institutional development, Spamann's ADR Index, Judicial Efficiency, Investor Protection, or Accounting Standards, as indicated. The dependent variable is Tobin's $q$. Openness to foreign investors is measured using investable dummies. Investable is a dummy variable that is set equal to one in years in which the firm is designated as investable. Firms are deemed investable if its stock is free from both country-level and firm-level restrictions on foreign investment. Firm size is measured as the log of annual sales in real \$U.S. Firm growth is measured as the (geometric) average real growth in sales over the prior two years. Global industry $q$ is calculated as the average $q$ of all global firms within each industry classification. ADR variables are dummy variables that are set equal to one in years in which the firm has an ADR. Country fund is a dummy variable indicating the existence of a closed-end country fund in the firm's country. Also estimated but not reported are a constant, and a full set of year dummies.

*** Statistical significance for the $1 \%$ level.

** Statistical significance for the $5 \%$ level.

* Statistical significance for the $10 \%$ level.

standards are sub-standard to 0.296 where accounting standards are well-developed (t-stat is 2.67). ${ }^{8}$ Our findings suggest that (almost) all firms enjoy an "investable premium", but the gains are greatest for firms from countries with weak country-level investor protection. These findings contrast notably with Bekaert et al. (2005). They show that the largest (economic) growth effects from stock market liberalizations dated using county-specific measures occur in countries with high-quality institutions. ${ }^{9}$ In the next section, we examine whether these "investable premia" accrue to all investable firms from countries with low-quality institution, or whether better-governed firms enjoy the majority of these value gains. ${ }^{10}$ To do so, we must first examine how the "investable premia" vary by the strength of corporate governance.

\subsection{Investability and corporate governance}

Next we examine how the "investable premia" documented earlier differ by the strength of corporate governance. The intuition is that if better-governed firms reap the largest value gains from becoming investable, then, a priori, we would expect that single-class share firms, and firms with concentrated inside ownership (as measured using closely-held shares as a \% of common shares outstanding) would enjoy the largest "investable premia". Recent works by Bae and Goyal (2010) and O'Connor (2012) suggest that

\footnotetext{
${ }^{8}$ The test-statistics are from a pooled regression which includes the investable dummy and the interaction of the investable dummy and an indicator variable which is 1 if country-level investor protection is high (above-median) (e.g. Investable * High IP, where IP is country-level investor protection). The test-statistic (t-stat) is taken from the interaction term.

${ }^{9}$ Our results may not be inconsistent with Bekaert et al. (2005) if the greater investment expected for investable firms from countries with low-quality institutions (caused by stock liberalizations increasing Tobin's $q$ ) does not translate into higher growth rates for these firms. Mitton (2006) does show that investability is associated with higher growth rates, but does not distinguish between firms from different countries.

${ }^{10}$ In a series of unreported regressions, we estimate the effect of investability on firm value using the different components of institutional development, namely, the level of voice and accountability, political stability, government effectiveness, regulatory quality, rule of law and control of corruption. Invariably we reach the same conclusions using the components of institutional development. These regressions are available from the corresponding author upon request.
} 
Table 6

Regression estimates of the effect of investability on firm value by level of institutional development.

\begin{tabular}{|c|c|c|c|c|c|c|}
\hline \multicolumn{7}{|l|}{ Panel A } \\
\hline & \multicolumn{3}{|c|}{ Single-class share firms } & \multicolumn{3}{|c|}{ Dual-class share firms } \\
\hline & $(1)$ & $(2)$ & $(3)$ & $(4)$ & $(5)$ & $(6)$ \\
\hline Investable & $\begin{array}{l}0.131^{\text {*** }} \\
(2.61)\end{array}$ & $\begin{array}{l}0.148^{\text {*** }} \\
(2.96)\end{array}$ & $\begin{array}{l}0.099^{* *} \\
(1.98)\end{array}$ & $\begin{array}{l}0.275^{*} \\
(1.93)\end{array}$ & $\begin{array}{l}0.295^{\text {** }} \\
(2.09)\end{array}$ & $\begin{array}{l}0.250^{*} \\
(1.84)\end{array}$ \\
\hline Time Dummies & Yes & Yes & Yes & Yes & Yes & Yes \\
\hline Controls & Yes & Yes & Yes & Yes & Yes & Yes \\
\hline \# Obs & 7091 & 7091 & 7091 & 2901 & 2901 & 2901 \\
\hline \multirow[t]{2}{*}{ R-Squared } & 0.001 & 0.001 & 0.001 & 0.109 & 0.108 & 0.007 \\
\hline & \multicolumn{6}{|c|}{ Significance tests: SC vs. DC } \\
\hline t-stat: SC vs. DC & \multicolumn{3}{|l|}{0.30} & & & \\
\hline \multicolumn{7}{|l|}{ Panel B } \\
\hline & \multicolumn{3}{|c|}{ High closely held shares (\%) } & \multicolumn{3}{|c|}{ Low closely held shares (\%) } \\
\hline & $(1)$ & $(2)$ & $(3)$ & $(4)$ & $(5)$ & (6) \\
\hline Investable & $\begin{array}{l}0.159^{*} \\
(1.95)\end{array}$ & $\begin{array}{l}0.155^{*} \\
(1.86)\end{array}$ & $\begin{array}{l}0.153^{*} \\
(1.86)\end{array}$ & $\begin{array}{l}-0.092 \\
(1.20)\end{array}$ & $\begin{array}{l}-0.093 \\
(1.24)\end{array}$ & $\begin{array}{l}-0.096 \\
(1.29)\end{array}$ \\
\hline Time dummies & Yes & Yes & Yes & Yes & Yes & Yes \\
\hline Controls & Yes & Yes & Yes & Yes & Yes & Yes \\
\hline \# Obs & 3240 & 3240 & 3240 & 2260 & 2260 & 2260 \\
\hline \multirow[t]{2}{*}{ R-squared } & 0.001 & 0.001 & 0.001 & 0.005 & 0.006 & 0.004 \\
\hline & \multicolumn{6}{|c|}{ Significance tests: HCHS v LCHS } \\
\hline t-stat: High vs. Low CHS & \multicolumn{6}{|l|}{$2.50^{* *}$} \\
\hline \multicolumn{7}{|c|}{$\begin{array}{l}\text { The table reports coefficient estimates from firm-fixed effects regressions with t-statistics (absolute value) adjusted for firm-level clustering presented in } \\
\text { parentheses underneath the coefficient estimates. Separate regressions are performed for single- and dual-class firms, and by level of closely-held shares. The } \\
\text { dependent variable is Tobin's } q \text {. Openness to foreign investors is measured using investable dummies. Investable is a dummy variable that is set equal to one in } \\
\text { years in which the firm is designated as investable., zero otherwise. Firm size is measured as the log of annual sales in real } \$ U . S \text {. Firm growth is measured as the } \\
\text { (geometric) average real growth in sales over the prior two years. Global Industry } Q \text { is calculated as the average } Q \text { of all global firms within each industry } \\
\text { classification. ADR variables are dummy variables that are set equal to one in years in which the firm has an ADR of the specified type. Country fund is a dummy } \\
\text { variable indicating the existence of a closed-end country fund in the firm's country. Also estimated but not reported is a constant and a full set of year dummies. } \\
* * * \text { Statistical significance for the } 1 \% \text { level. } \\
* * \text { Statistical significance for the } 5 \% \text { level. }\end{array}$} \\
\hline
\end{tabular}

this is the case. Using the liberalization of the Korean equity market in 1992, the former show that better-governed Korean firms enjoy the largest value gains. ${ }^{11}$ O'Connor (2012) finds likewise using firm-specific measures of equity market liberalizations (i.e. investable dummies), and using firms from 20 emerging market countries. ${ }^{12}$ Thus, a priori, we would expect to find the same.

In Table 6 we explore the relationship between "investable premia" and corporate governance, by estimating Eq. (1) separately for single- and dual-class investable firms and for firms with high (above-median) and low (below-median) closely held-shares. Since the incentives of controlling insiders and minority outsiders are likely to be better-aligned (but not always) the greater the ownership (cashflow) stake of the controlling insider, then, all else being equal, foreign institutional investors are likely to invest disproportionately more in these firms once these firms become investable. As a result, we would expect that investable firms with high pre-investable levels of closely-held shares (as a \% of total common shares outstanding) reap the largest value gains from becoming investable. For firms with much lower levels of insider ownership, the level of foreign investment is likely to be much lower, since expropriation risk is much higher, hence resulting in much lower, if any, value gains. Panel A suggests that single and dual-class share firms enjoy sizable "investable premia". However, at odds with our prior expectations, and with Bae and Goyal (2010), better-governed single-class share firms do not have larger "investable premia" when compared to dual-class share firms. Both enjoy comparably large "investable premia”. The fact that dual-class share firms enjoy an "investable premium" is not surprising. What is surprising is that their premium is comparable to single-class share investable firms. In part, we believe that this finding may arise because of the manner in which our dual-class share dummy variable is constructed. Using Worldscope, we are only able to determine whether firms are currently (presently) multiple share companies. Hence, firms that were, but are not now, or firms that currently are, but previously were not, will be incorrectly attributed as single and dual-class share firms, respectively.

\footnotetext{
11 They use three measures to capture the different corporate governance practices of Korean firms. They use Chaebol affiliation, the ownership stake of the largest shareholder, and a dividend paying dummy.

${ }^{12}$ O'Connor (2012) also uses three measures to measure differences in corporate governance practices in emerging market firms. They are a dual-class/ single-class share indicator, and two agency cost measures, namely the ratio of sales-to-assets, and operating expenses-to-sales.
} 
The coefficient estimates from estimating Eq. (1) for investable firms with high and low pre-investable levels of closely-held shares (as a \% of total shares outstanding) are more in line with our prior expectations, and are consistent with the findings of Bae and Goyal (2010) and O'Connor (2012). Investable firms with high pre-investable levels of closely-held shares enjoy a large and statistically significant "investable premium". The coefficient estimates range from 0.153 to 0.159 , which suggest that the value gains from becoming investable for these firms range from $10.27 \%($ i.e. $(0.153 / 1.49) * 100)$ to $10.67 \%$ (i.e. $0.159 / 1.49$ ) * 100) for the median firm.

In contrast, for investable firms with less concentrated inside ownership, there is no "investable premium". For these firms, the coefficient estimates on the investable dummies are small, negative, and always statistically indifferent to zero. Furthermore, and more telling, the coefficient estimates on the investable dummies between high and low closely-held share firms is positive and statistically significant (t-stat is 2.50). ${ }^{13}$ These findings are, in particular, consistent with Bae and Goyal (2010). Using cross-sectional regressions of abnormal returns on governance-related variables calculated around the month of the liberalization of the Korean equity market, they show that the abnormal returns are positively related to the equity ownership of the largest shareholder. We show that "investable premia" increase in the level of pre-investable closely-held shares (as a \% of total shares outstanding). Overall, our findings suggest that better-governed firms reap the largest value gains from becoming investable.

\subsection{Investability, country-level investor protection and corporate governance}

In addition to the tests undertaken in Bae and Goyal (2010) and O'Connor (2012), we are, given our inclusion of country-level variables able to perform a number of additional tests, not possible in the Bae and Goyal (2010) paper (because it is a single-country study), and not undertaken by O'Connor (2012). These tests center around analysing whether corporate and country-level investor protection complement or substitute for each other. On one hand, if country-level protection and corporate governance complement each other, then the "investable premia" should be greatest for firms when both country and corporate governance is strong. If not, and they substitute for one another, better-governed firms in countries where country-level investor protection is weak, should, all else equal, experience the largest value gains. If this is the case, it would suggest that foreign investors value good corporate governance more highly in countries where country governance is weak. In addition, this substitution effect would also imply that poorly-governed firms could substitute poor corporate governance for superior country governance. If this is the case, which would in turn suggest that foreign investors invest primarily based on country and not corporate governance attributes, then poorly-governed firms from countries with high-quality institutions would reap larger value gains that their counterpart from countries with low-quality institutions. Hence, if country and corporate governance substitute for one another, this then suggests that both better-governed firms from countries with low-quality institutions, and poorly-governed firms from countries with high-quality institutions would reap large "investable premia".

In Table 7, we look at how corporate and country governance together can explain differences in the value gains from becoming investable. To do so, we undertake the same analysis as that performed in Tables 6 , but now by each measure of country-level investor protection. The coefficient estimates are presented in Table 7. There are several important findings. First, poorly-governed firms (as measured using closely-held shares (\%)) never experience an "investable premium". Irrespective of the measure of country-level investor protection used, the coefficient estimates are never positive and statistically different to zero. In one instance (in countries with low levels of shareholder rights measured using Spamann's revised ADR Index), investability results in an "investable discount". Second, better-governed firms (measured using closely-held shares (\%)) only enjoy "investable premia" where country-level investor protection is weak. For these firms, the "investable premia” are large (the coefficient estimates range from 0.320 (using Spamann's ADR Index) to 1.233 using the measure of institutional development). Where country-level investor protection is strong, better-governed firms no longer enjoy an "investable premium". In all five instances, the coefficient estimates are positive but never statistically significant. Then it comes as no surprise that across all five measures of investor protection, better-governed firms enjoy a larger and statistically significant "investable premia" where investor protection is weak (see row labeled "t-stat: High vs. Low"). Third, the findings using single and dual-class share firms are less conclusive. In three of the five cases, single-class share firms from countries with weak investor protection enjoy statistically larger "investable premia" when compared to single-class share investable firms in countries with strong investor protection (institutional development ( $\mathrm{t}$-stat is 2.15), Spamann ADR Index ( $\mathrm{t}$-stat is 1.67), and Accounting Disclosure (t-stat is 2.66). We draw similar conclusions for dual-class share firms. Dual-class share firms in countries with strong investor protection never enjoy an "investable premium". Their counterparts in countries where investor protection is weak do, and in three of the five cases, the difference in "investable premia" between the two-sets of firms is statistically significant (Institutional development (t-stat is 1.71), Judicial Efficiency ( $t$-stat is 1.85), and Investor Protection (t-stat is 1.70)). Finally, we find that in countries with weak investor protection, single-class share investable firms never enjoy a statistically larger "investable premium" when compared to dual-class share firms (see row labeled "t-stat: Low vs. Low"). ${ }^{14}$

These findings suggest that corporate and country governance substitute for one another; single-class share firms substitute poor country governance for high-quality corporate governance. In turn, while we don't directly observe the portfolio allocation decisions of foreign investors in each firm, these findings suggest that corporate and not country governance attributes matter

\footnotetext{
13 The test statistics are identical to those reported in Table 5, but now the interaction term is between the investable dummy and either the dual-class share dummy or an indicator which is 1 if the firm is deemed a "High Closely-Held Share" firm, respectively.

14 The test-statistics are the same as those reported in Table 6, but the regressions are restricted to firms from countries with weak country-level investor protection.
} 
Table 7

Regression estimates of the effect of investability on firm value by level of corporate governance and country-level investor protection.

\begin{tabular}{|c|c|c|c|c|c|c|c|c|}
\hline & \multicolumn{4}{|c|}{ Ownership structure } & \multicolumn{4}{|c|}{ Closely held shares (\%) } \\
\hline & \multicolumn{2}{|c|}{ Single-class shares } & \multicolumn{2}{|c|}{ Dual-class shares } & \multicolumn{2}{|c|}{ High closely held shares (\%) } & \multicolumn{2}{|c|}{ Low closely held shares (\%) } \\
\hline \multicolumn{9}{|c|}{ Institutional development } \\
\hline & $\begin{array}{l}\text { High ID } \\
\text { (1) }\end{array}$ & $\begin{array}{l}\text { Low ID } \\
(2)\end{array}$ & $\begin{array}{l}\text { High ID } \\
\text { (3) }\end{array}$ & $\begin{array}{l}\text { Low ID } \\
(4)\end{array}$ & $\begin{array}{l}\text { High ID } \\
\text { (5) }\end{array}$ & $\begin{array}{l}\text { Low ID } \\
(6)\end{array}$ & $\begin{array}{l}\text { High ID } \\
\text { (7) }\end{array}$ & $\begin{array}{l}\text { Low ID } \\
(8)\end{array}$ \\
\hline Investable & $\begin{array}{l}0.050 \\
(1.05)\end{array}$ & $\begin{array}{l}0.937^{* *} \\
(3.43)\end{array}$ & $\begin{array}{l}0.004 \\
(0.03)\end{array}$ & $\begin{array}{l}0.739^{* * *} \\
(2.80)\end{array}$ & $\begin{array}{l}0.034 \\
(0.52)\end{array}$ & $\begin{array}{l}1.233^{* * *} \\
(3.85)\end{array}$ & $\begin{array}{l}-0.058 \\
(0.83)\end{array}$ & $\begin{array}{l}0.116 \\
(0.90)\end{array}$ \\
\hline R-squared & 0.010 & 0.012 & 0.015 & 0.008 & 0.005 & 0.005 & 0.002 & 0.001 \\
\hline $\begin{array}{l}\text { Significance tests } \\
\text { t-stat: High vs. Low } \\
\text { t-stat: Low vs. Low }\end{array}$ & $\begin{array}{l}2.15^{* *} \\
0.28\end{array}$ & & $1.71^{*}$ & & $\begin{array}{l}2.86^{* * *} \\
2.67^{* * *}\end{array}$ & & 0.67 & \\
\hline \multicolumn{9}{|c|}{ Spamann ADR Index (1997 values) } \\
\hline & $\begin{array}{l}\text { High ADRI } \\
\text { (1) }\end{array}$ & $\begin{array}{l}\text { Low ADRI } \\
(2)\end{array}$ & $\begin{array}{l}\text { High ADRI } \\
\text { (3) }\end{array}$ & $\begin{array}{l}\text { Low ADRI } \\
\text { (4) }\end{array}$ & $\begin{array}{l}\text { High ADRI } \\
\text { (5) }\end{array}$ & $\begin{array}{l}\text { Low ADRI } \\
(6)\end{array}$ & $\begin{array}{l}\text { High ADRI } \\
\text { (7) }\end{array}$ & $\begin{array}{l}\text { Low ADRI } \\
\text { (8) }\end{array}$ \\
\hline Investable & $\begin{array}{l}0.137^{* *} \\
(2.27)\end{array}$ & $\begin{array}{l}0.273^{* * *} \\
(3.29)\end{array}$ & $\begin{array}{l}0.017 \\
(0.15)\end{array}$ & $\begin{array}{l}0.256 \\
(1.39)\end{array}$ & $\begin{array}{l}0.135 \\
(1.58)\end{array}$ & $\begin{array}{l}0.320^{*} \\
(1.83)\end{array}$ & $\begin{array}{l}-0.046 \\
(0.66)\end{array}$ & $\begin{array}{l}-0.148^{*} \\
(1.78)\end{array}$ \\
\hline R-squared & 0.004 & 0.022 & 0.013 & 0.014 & 0.001 & 0.001 & 0.001 & 0.001 \\
\hline $\begin{array}{l}\text { Significance tests } \\
\text { t-stat: High vs. Low } \\
\text { t-stat: Low vs. Low }\end{array}$ & $\begin{array}{l}1.67^{*} \\
0.47\end{array}$ & & 1.51 & & $\begin{array}{l}1.74^{*} \\
2.47^{* * *}\end{array}$ & & 0.89 & \\
\hline \multicolumn{9}{|l|}{ Judicial efficiency } \\
\hline & $\begin{array}{l}\text { High JE } \\
\text { (1) }\end{array}$ & $\begin{array}{l}\text { Low JE } \\
(2)\end{array}$ & $\begin{array}{l}\text { High JE } \\
\text { (3) }\end{array}$ & $\begin{array}{l}\text { Low JE } \\
(4)\end{array}$ & $\begin{array}{l}\text { High JE } \\
\text { (5) }\end{array}$ & $\begin{array}{l}\text { Low JE } \\
\text { (6) }\end{array}$ & $\begin{array}{l}\text { High JE } \\
\text { (7) }\end{array}$ & $\begin{array}{l}\text { Low JE } \\
\text { (8) }\end{array}$ \\
\hline Investable & $\begin{array}{l}0.121^{* *} \\
(2.25)\end{array}$ & $\begin{array}{l}0.360^{*} \\
(1.68)\end{array}$ & $\begin{array}{l}0.086 \\
(0.58)\end{array}$ & $\begin{array}{l}0.255^{* * *} \\
(2.59)\end{array}$ & $\begin{array}{l}0.051 \\
(0.71)\end{array}$ & $\begin{array}{l}0.926^{* * *} \\
(3.95)\end{array}$ & $\begin{array}{l}-0.056 \\
(0.75)\end{array}$ & $\begin{array}{l}0.015 \\
(0.18)\end{array}$ \\
\hline R-squared & 0.013 & 0.010 & 0.011 & 0.015 & 0.001 & 0.001 & 0.001 & 0.001 \\
\hline $\begin{array}{l}\text { Significance tests } \\
\text { t-stat: High vs. Low } \\
\text { t-stat: Low vs. Low }\end{array}$ & $\begin{array}{l}1.05 \\
0.47\end{array}$ & & $1.85^{*}$ & & $\begin{array}{l}3.02^{\text {*** }} \\
2.45^{* * *}\end{array}$ & & 0.32 & \\
\hline \multicolumn{9}{|l|}{ Investor protection } \\
\hline Investable & $\begin{array}{l}\text { High IP } \\
(1) \\
0.134 \\
(1.56)\end{array}$ & $\begin{array}{l}\text { Low IP } \\
(2) \\
0.132^{* *} \\
(2.35)\end{array}$ & $\begin{array}{l}\text { High IP } \\
(3) \\
-0.107 \\
(0.66)\end{array}$ & $\begin{array}{l}\text { Low IP } \\
(4) \\
0.250^{*} \\
(1.72)\end{array}$ & $\begin{array}{l}\text { High IP } \\
(5) \\
0.037 \\
(0.47)\end{array}$ & $\begin{array}{l}\text { Low IP } \\
(6) \\
0.453^{* * *} \\
(2.81)\end{array}$ & $\begin{array}{l}\text { High IP } \\
(7) \\
-0.174 \\
(1.16)\end{array}$ & $\begin{array}{l}\text { Low IP } \\
(8) \\
0.043 \\
(0.94)\end{array}$ \\
\hline R-squared & 0.023 & 0.006 & 0.013 & 0.015 & 0.001 & 0.001 & 0.001 & 0.001 \\
\hline $\begin{array}{l}\text { Significance tests } \\
\text { t-stat: High vs. Low } \\
\text { t-stat: Low vs. Low }\end{array}$ & $\begin{array}{l}0.02 \\
0.18\end{array}$ & & $1.70^{*}$ & & $\begin{array}{l}2.85^{* * *} \\
2.56^{* * *}\end{array}$ & & 0.67 & \\
\hline \multicolumn{9}{|c|}{ Accounting disclosure index } \\
\hline & $\begin{array}{l}\text { High ADI } \\
\text { (1) }\end{array}$ & $\begin{array}{l}\text { Low ADI } \\
(2)\end{array}$ & $\begin{array}{l}\text { High ADI } \\
\text { (3) }\end{array}$ & $\begin{array}{l}\text { Low ADI } \\
(4)\end{array}$ & $\begin{array}{l}\text { High ADI } \\
\text { (5) }\end{array}$ & $\begin{array}{l}\text { Low ADI } \\
\text { (6) }\end{array}$ & $\begin{array}{l}\text { High ADI } \\
\text { (7) }\end{array}$ & $\begin{array}{l}\text { Low ADI } \\
\text { (8) }\end{array}$ \\
\hline Investable & $\begin{array}{l}0.065 \\
(1.14)\end{array}$ & $\begin{array}{l}0.418^{* * *} \\
(3.19)\end{array}$ & $\begin{array}{l}0.070 \\
(0.35)\end{array}$ & $\begin{array}{l}0.201^{* *} \\
(2.18)\end{array}$ & $\begin{array}{l}0.046 \\
(0.65)\end{array}$ & $\begin{array}{l}0.656^{* * *} \\
(2.75)\end{array}$ & $\begin{array}{l}-0.051 \\
(0.70)\end{array}$ & $\begin{array}{l}-0.011 \\
(0.12)\end{array}$ \\
\hline R-squared & 0.008 & 0.020 & 0.010 & 0.017 & 0.001 & 0.001 & 0.001 & 0.001 \\
\hline $\begin{array}{l}\text { Significance tests } \\
\text { t-stat: High vs. Low } \\
\text { t-stat: Low vs. Low }\end{array}$ & $\begin{array}{l}2.66^{* * *} \\
0.47\end{array}$ & & 1.27 & & $\begin{array}{l}2.94^{* * *} \\
2.84^{* * *}\end{array}$ & & 0.21 & \\
\hline
\end{tabular}

The table reports coefficient estimates from firm-fixed effects regressions with t-statistics (absolute value) adjusted for firm-level clustering presented in parentheses underneath the coefficient estimates. Separate regressions are performed for single- and dual-class investable firms, and high and low closely held share (\%) firms, by level of country-level investor protection. Investor protection is measured using either institutional development, Spamann's ADR Index, Judicial Efficiency, Investor Protection, or Accounting Standards, as indicated. The dependent variable is Tobin's $q$. Openness to foreign investors is measured using investable dummies. Investable is a dummy variable that is set equal to one in years in which the firm is designated as investable., zero otherwise. Also estimated but not reported is a constant, control variables and a full set of year dummies.

*** Statistical significance for the $1 \%$ level.

** Statistical significance for the $5 \%$ level.

* Statistical significance for the $10 \%$ level.

more for foreign investors. These findings also confirm the substitute nature of the relationship that exists between corporate and country governance in emerging markets (Chen et al., 2009; Durnev \& Kim, 2005; Klapper \& Love, 2004). Durnev and Kim (2005) document a positive relationship between corporate governance and firm value in emerging markets, and in turn, show that this positive relationship is more pronounced in countries with weak legal regimes. Klapper and Love (2004) show likewise, this time 
using measures of firm performance. Chen et al. (2009) show that in emerging markets, firm-level governance and country governance substitute for one another in determining the cost of equity capital. Hence, foreign investors appear to value good (corporate) governance more highly, when it is most required i.e. when country governance is weak. ${ }^{15}$ Our findings also suggest that this is the case. Foreign investors value better-governed firms highly (see Table 6), but value better-governed firms from countries with low-quality institutions, the highest (see Table 7). Finally, our findings also contrast notably with the value gains from another aspect of corporate internationalization, namely international cross-listings. Hope, Kang, and Zang (2007) and Fresard and Salva (2010) show that the value gains from international cross-listing in the U.S. are greater for exchange-traded firms (Levels 2 and 3 ADR) from countries with high-quality institutions. The former show that "cross-listing premia" increase in the quality of home-country (as opposed to host-country) institutions. The latter find that "foreign firm discounts" increase in the quality of home-country institutions. In contrast, we find that investability confers the largest "investable premia" on firms from low-quality regimes.

As a result, and thus non-surprisingly, we find no evidence to suggest that investable firms can substitute poor corporate governance for superior country governance. For example, using closely-held shares (as a \% of total shares outstanding) to measure corporate governance, we find no evidence to suggest that firms with low pre-investable levels of inside ownership (presumably poor governance) from countries with high-quality institutions gain from becoming investable. Irrespective of the quality of home country institutions, there are no "investable premia" for these firms. These findings, and the findings presented for better-governed firms, suggest that corporate, and not country governance, matters most to foreign investors. If this was not the case, then poorly-governed firms from countries with high-quality institutions would reap large "investable premia". They don't, although with one exception, the case of dual-class share investable firms.

For dual-class firms, the coefficient estimates run contrary to our prior expectations. Dual-class firms from countries with low-quality institutions, and not their counterparts from countries with high-quality regimes, enjoy large "investable premia". These findings extend our analysis from earlier (see Table 6). They suggest that the "investable premium" that we documented earlier for dual-class firms are the sole preserve of dual-class firms in countries with low-quality institutions. While we don't try and uncover the sources of these value gains for dual-class firms in this paper, our findings are consistent with recent evidence presented by Flavin and O'Connor (2011). They show that investability is associated with a shift towards the greater use of long-term debt for these firms. Their results imply that the cost of (long-term) debt capital is lower for these firms, once they become investable. This effect, likely coupled with others, may well explain the "investable premia" that we observe for these firms. Along these same lines, Lin, Ma, Malatesta, and Xuan (2011) show that borrowing costs are much higher for firms with excess control rights (dual-class share firms), and as a result, dual-class firms predominantly use more short-term debt financing (see Flavin \& O'Connor, 2011). Consequently, Lin, Ma, and Xuan (2010) find that firms with excess control rights are more financially constrained. In turn, financing constraints serve to partially explain the lower valuations of these firms. Our findings, together with those of Flavin and O'Connor (2011) suggest that investability relaxes the financing constraints of dual-class firms (in countries with low-quality institutions), which in turn, enhances their value. In contrast, dual-class share firms domiciled in countries with superior institutions do not enjoy any value gains. ${ }^{16}$

\section{Conclusion}

This paper investigates the relationship between a firm's corporate governance, their value, country-level investor protection and investability. We extended the approach of Bae and Goyal (2010) to a multi-country setting, and find that their insights on the effect of differences in corporate governance within firms on their valuation in emerging markets do indeed carry over to other countries.

We go a step further and apply the methodology of Mitton and O'Connor (2012) to see whether investors care more about the firm's corporate governance, or the country's level of institutional development. Using a series of firm fixed-effects regressions, we find that a firm's corporate governance matters more-there is a premium to investing in firms with good governance structures in countries with weak investor protection.

\section{References}

Anderson, A., \& Gupta, P. (2009). A cross-country comparison of corporate governance and firm performance: Do financial structure and legal system matter? Journal of Contemporary Accounting and Economics, 5, 61-79.

Bae, K., \& Goyal, V. (2010). Equity market liberalization and corporate governance. Journal of Corporate Finance, 16, 609-621.

Bekaert, G., Harvey, C., \& Lundblad, C. (2001). Emerging equity markets and economic development. Journal of Development Economics, 66, 465-504.

Bekaert, G., Harvey, C., \& Lundblad, C. (2005). Does financial liberalization spur economic growth? Journal of Financial Economics, 77, 3-55.

Chen, K., Chen, Z., \& Wei, K. (2009). Legal protection of investors, corporate governance, and the cost of equity capital. Journal of Corporate Finance, 15, 273-289.

Claessens, S., Djankov, S., Fan, J., \& Lang, L. (2002). Disentangling the incentives and entrenchment effects of large shareholders. Journal of Finance, 57, $2741-2771$.

Cueto, D. (2013). Substitutability and complementarity of corporate governance mechanisms in Latin America. International Review of Economics and Finance, 25 , $310-325$.

\footnotetext{
15 Using a sample of developed market firms, Anderson and Gupta (2009) show that corporate governance and country attributes (i.e. financial structure and legal system) complement one another. Better-governed firms are more high valued in market-based/common law country combinations (as opposed to bankbased and civil law countries).

${ }^{16}$ In an additional analysis (unreported) we undertake the same analysis, but now using the components of the institutional development measure. Almost without exception, we reach the same conclusions. These tables containing these coefficient estimates are available from the corresponding author upon request.
} 
DeAngelo, H., \& DeAngelo, L. (1985). Managerial ownership of voting rights: A study of public corporations with dual classes of common stock. Journal of Financial Economics, 14, 33-39.

Djankov, S., La Porta, R., Lopez-de-Silanes, F., \& Shleifer, A. (2008). The law and economics of self-dealing. Journal of Financial Economics, 88, $430-465$.

Doidge, C., Karolyi, G., \& Stulz, R. (2004). Why are foreign firms listed in the U.S. worth more? Journal of Financial Economics, 71, $205-238$.

Doidge, C., Karolyi, G., \& Stulz, R. (2009). Has New York become less competitive in global markets? Evaluating foreign listing choices over time. Journal of Financial Economics, 91, 253-287.

Durnev, A., \& Kim, E. (2005). To steal or not to steal: Firm attributes, legal environment, and valuation. Journal of Finance, Vol. 60, $1461-1493$.

Durnev, A., \& Kim, E. (2007). Explaining differences in the quality of governance among companies: Evidence from emerging markets. Journal of Applied Corporate Finance, 19, 16-24.

Flavin, T., \& O'Connor, T. (2011). The effects of ownership structure and corporate governance on corporate financing decisions. Unpublished Working Paper (Department of Economics, Finance, and Accounting, NUI Maynooth).

Fresard, L., \& Salva, C. (2010). The foreign firm discount. Unpublished Working Paper (World Bank, HEC School of Management, Paris).

Gamra, S. (2009). Does financial liberalization matter for emerging East Asian economies growth? Some new evidence. International Review of Economics and Finance, 18, 392-403.

Gozzi, J. C., Levine, R., \& Schmukler, S. (2008). Internationalization and the evolution of corporate valuation. Journal of Financial Economics, 88, 607-632.

Grossman, S., \& Hart, O. (1988). One share-one vote and the market for corporate control. Journal of Financial Economics, $20,175-202$.

Henry, P. B. (2000). Do stock market liberalizations cause investment booms? Journal of Financial Economics, 58, $301-334$.

Hope, O., Kang, T., \& Zang, Y. (2007). Bonding to the improved disclosure environment in the U.S: firms' listing choices and their capital market consequences. Journal of Contemporary Accounting and Economics, 3, 1-33.

Kaufmann, D., Kraay, A., \& Mastruzzi, M. (2007). Governance matters VI: Aggregate and individual governance indicators 1996-2006. Unpublished Working Paper (World Bank).

Kim, E., \& Signal, V. (2000). Does financial liberalization reduce financing constraints? Financial Management, 32, 5-34.

Klapper, L., \& Love, I. (2004). Corporate governance, investor protection, and performance in emerging markets. Journal of Corporate Finance, $10,703-728$.

La Porta, R., Lopez-de-Silanes, F., Shleifer, A., \& Vishny, R. (1998). Law and finance. Journal of Political Economy, 106, $1113-1155$.

La Porta, R., Lopez-de-Silanes, F., \& Shleifer, A. (2006). What works in securities laws? Journal of Finance, 1-32.

Lin, C., Ma, Y., \& Xuan, Y. (2010). Ownership structure and financing constraints: Evidence from structural estimation. Unpublished Working Paper (Harvard Business School).

Lin, C., Ma, Y., Malatesta, P., \& Xuan, Y. (2011). Ownership structure and the cost of corporate borrowing. Journal of Finance, $100,1-23$.

Lins, K. (2003). Equity ownership and firm value in emerging markets. Journal of Financial and Quantitative Analysis, 38, 159-184.

Masulis, R., Wang, C., \& Xie, F. (2009). Agency costs at dual-class companies. Journal of Finance, 64, $1697-1727$.

McCahery, J., Sautner, Z., \& Starks, L. (2010). Behind the scenes: The corporate governance preferences of institutional investors. Unpublished Working Paper No: 235/2009 (European Corporate Governance Institute).

Mitton, T. (2002). A cross-firm analysis of the impact of corporate governance on the East Asian financial crisis. Journal of Financial Economics, 64, $215-241$.

Mitton, T. (2006). Stock market liberalization and operating performance at the firm level. Journal of Financial Economics, 81, $625-647$.

Mitton, T., \& O'Connor, T. (2012). Investability and firm value. European Financial Management, 18, 731-761.

O'Connor, T. (2010). Are there permanent valuation gains from becoming investable? Banking E Finance Letters, 10, 419-429.

O'Connor, T. (2012). Investability, corporate governance and firm value. Research in International Business and Finance, 26, $120-136$.

Patro, D. (2005). Stock market liberalization and emerging market country fund premiums. Journal of Business, 78, $135-168$.

Petersen, M. (2009). Estimating standard errors in finance panel data sets: Comparing approaches. Review of Financial Studies, $22,435-480$.

Spamann, H. (2010). The "anti-director rights index" revisited. Review of Financial Studies, 23, 467-486. 